\title{
Az egyházi fenntartású iskolák és a szelekció, szegregáció kapcsolata
}

2010 óta jelentốsen megnótt mind az egyházi fenntartású iskolák, mind az egyházi fenntartású iskolák tanulóinak aránya, igy az egyházi fenntartók iskolapolitikája képes hatást gyakorolni az oktatási rendszer egészére. Ugyanebben az idôszakban a kormányzat részéról egyértelmúen azonositható az egyházi fenntartókat preferáló viselkedés (pl. kommunikáció, finanszírozás, diszkrecionális jogosultságok biztositása). Figyelembe véve e két folyamatot, illetve a magyar oktatási rendszert jellemzó szélsóséges, szociokulturális, szocioökonómiai alapú szelektivitást, indokolt az egyházi iskola-hatás vizsgálata. A kutatás azoknak a 2, 3 és 4 iskolás településeknek vizsgálta a szelekciós struktúráját, ahol a legnagyobb hatáspotenciállal rendelkezó felekezeteknek (katolikus, református, evangélikus, görögkatolikus) volt 2016-ban iskolájuk.

A z egyházi fenntartású iskolák térfoglalásának alakulása a magyar közoktatás rendszerében a magyarázat egyik fele arra, miért égető szükség a címben jelzett összefüggés vizsgálata. Míg a 2000-es évek elején mindössze 5-6\% volt az egyházi iskolák aránya, addig 2014-re ez a szám 15-16\%-ra nőtt (Hermann és Varga, 2016). Az egyházi iskolák tanulói létszáma is hasonlóan alakult: 4,9\%-ról 13,8\%-ra nőtt (Hermann és Varga, 2016). Ezzel az egyházi expanzió mértéke elérte azt a határt, amikor a fenntartói viselkedés (ld. iskolapolitika) az oktatási rendszer egészére képes hatást gyakorolni.

A magyarázat másik fele, hogy 2010 után az egyházi iskolafenntartók a kormányzat részéröl olyan megkülönböztetett elönyökhöz jutottak - például szabályozás, finanszírozás terén -, mely az iskolaválasztással kapcsolatos döntési helyzetben lévő tehetősebb szülöi réteget az egyházi iskolák felé tereli (Ercse, 2018).

A fent említett két jelenség együttes hatása komoly aggodalomra ad okot, hiszen a magyar oktatási rendszer legégetőbb problémáját, a szélsőséges szelektivitást és esélyegyenlőtlenséget tovább súlyosbíthatja. Mivel az iskola által preferált készségek, képességek, elözetes ismeretek, viselkedési kódex és kommunikációs forma kulturálisan determinált, azaz jellemzően a középosztályból érkezett tanulók sajátja, ilyen módon válik szelekciós kritériummá a szociokulturális, szocio-ökonómiai háttér (Nahalka és Zempléni, 2014; Radó, 2018). Hazai (Országos kompetenciamérések - OKM) és nemzetközi (pl. PISA, PIRLS, TIMSS) mérések eredményei alapján pontosan tudjuk, hogy egy gyermek boldogulási esélyeit meghatározó minőségi oktatáshoz való hozzáférését, tanulási teljesítményét, tanulói karrierjének ívét döntő mértékben a családi háttere határozza meg (Csapó, Fejes, Kinyó és Tóth, 2019; Fehérvári és Széll, 2014; OECD, 2016). 
Nemzetközi (OECD, 2012) és hazai (OKM, Kopp, 2015) tanulói teljesítményvizsgálatok egyaránt arra a megállapításra jutottak, hogy az egyházi fenntartású intézmények magasabb teljesítményét a kedvezőbb szülöi háttér nagyban magyarázza.

A nemzetközi diskurzusban jelen van az arról való gondolkodás, hogy a felekezeti iskolák felvállalt szelekciós funkciójának - társadalmi csoporthoz tartozás, etnikum, illetve világnézet mentén - milyen következményeivel lehet számolni (pl. Maussen és Bader, 2015; Merry, 2015), hazai térben azonban csak szigetszerüen (pl. L. Ritók, 2018; Lannert, Németh és Szécsi 2018; Zolnay, 2018) tapasztalható e problématerület nyílt artikulációja.

\section{Kérdések}

A fentiek ismeretében tehát fontosnak tartom az egyházi iskolák szelekcióban betöltött szerepének részletes vizsgálatát, az úgynevezett egyháziiskola-hatás azonosítását. Ennek érdekében két kutatási kérdést fogalmaztam meg.

(1) Azokon a 2, 3, 4 feladatellátási hellyel $(\mathrm{FEH})^{*}$ rendelkező településeken, ahol van egyházi iskolafenntartó, megfigyelhetö-e a településen belüli, iskolák közötti olyan szelekció, amelyben kimutatható az egyházi fenntartású iskolák részéről a magas státuszú családok gyermekei beiskolázásának nagyobb aránya?

A feladatellátási hely egy adott iskolának az a része, amely földrajzilag egy helyen (telephelyen) található, és benne csak egy típusú képzés zajlik. A könnyebb olvashatóság kedvéért a továbbiakban a FEH-et iskola, illetve intézmény szavakkal fogom helyettesíteni, de fontos tudni, hogy egy iskola egy adott telephelyén több feladatellátási hely is létezhet.

Az ilyen településeken - méretük miatt -

könnyebben és egyértelmüen kimutatható, hogy a tanulói populáció milyen mintázatok alapján oszlik el az oktatási intézmények között. Egy felekezeti általános iskola részt vesz a kötelező felvételt biztosító iskola feladatainak ellátásában, a kormányhivatallal és az állami fenntartóval történt létszám-megállapodásnak megfelelően, de minimum a maximális tanulói létszám 25\%-a keretéig. Ez azt jelenti, hogy az egyházi általános iskola a nemzeti köznevelésről szóló 2011. évi CXC. törvény által biztosított diszkrecionális jog alapján
Mivel az iskola által preferált készségek, képességek, elózetes ismeretek, viselkedési kódex és kommunikációs forma kulturálisan determinált, azaz jellemzóen a középosztályból érkezett tanulók sajátja, ilyen módon válik szelekciós kritériummá a szociokulturális, szocio-ökonó-

miai háttér (Nahalka és Zempléni, 2014; Radó, 2018). Hazai (Országos kompetenciamérések - OKM) és nemzetközi (pl. PISA, PIRLS, TIMSS) mérések eredményei alapján pontosan tudjuk, hogy egy gyermek boldogulási esélyeit meghatározó minóségi oktatáshoz való hozzáférését, tanulási teljesitményét, tanulói karrierjének ivét döntố mértékben a családi háttere határozza meg (Csapó,

Fejes, Kinyó és Tóth, 2019; Fehérvári és Széll, 2014; OECD, 2016). Nemzetközi (OECD, 2012) és hazai (OKM, Kopp, 2015) tanulói teljesítményvizsgálatok egyaránt arra a megállapításra jutottak, hogy az egyházi fenntartású intézmények magasabb teljesítményét a kedvezóbb szülói háttér nagyban magyarázza. 
tanulóit a fennmaradó létszámban/arányban a saját kritériumrendszere alapján válogathatja ki. Amennyiben szerkezetváltó (6 vagy 8 évfolyamos) gimnáziumi képzési programot is kínál, ott már nincs (körzetes) felvételi kötelezettsége, a tanulók 100\%-a esetében érvényesítheti a saját felvételi politikáját. Ebből következik a második kutatási kérdés.

(2) Amennyiben egy felekezeti fenntartó 6 vagy 8 évfolyamos és általános iskolai képzési programot is kínál, a két képzési program között kimutatható-e a tanulói összetétel különbsége a szociális helyzet és egyéb társadalmi hátrányok mentén?

A kutatás tehát arra keresi a választ, hogy az ország két-, három-, illetve négyiskolás településein, ahol olyan felekezeti fenntartók vannak jelen, melyek intézményeinek, illetve tanulóinak száma akkora, hogy az oktatás egész rendszerére hatást gyakoroljanak, megfigyelhetö-e ezen felekezetek részéről a magasabb státuszú családok gyermekeinek elönyben részesítése.

A szelekciót sokféleképpen lehet vizsgálni. Ilyen például a már említett felvételi eljárások rendje, tartalma, következtetéseket lehet levonni a tanulók szüleinek iskolázottsági adataiból, vagy esetleg társadalmi hátrányokról szóló indikátorok alapján (SNI-arány, HHH-arány stb.). Jelen vizsgálat tárgyai a településeken található feladatellátási helyek, fó fókusza ezek családiháttér-indexeinek átlaga, a halmozottan hátrányos helyzetüek és roma tanulók aránya.

\section{Módszertan}

A feltett kérdésekre az Országos kompetenciamérés (OKM) adatbázisának másodelemzésével kerestem a választ. Magyarországon 2001 óta minden évben, 2006 óta a jelenleg ismert tematikának megfelelően a 6., 8. és 10 . évfolyamos tanulók szövegértési és matematikai eszköztudását méri fel a vizsgálat. A mérésen való részvétel adott évfolyamokon minden tanuló számára kötelező, kivéve néhány speciális esetet, mint például a sajátos nevelési igény bizonyos fajtái vagy a kézsérülés. 2008 óta rendelkeznek a tanulók egyéni azonosítóval, így lehetséges az egyéni nyomon követés is. Mivel a teljesítményt számos háttértényező befolyásolja (a tanuló családi háttere, szociokulturális helyzete, az iskola/ intézményi körülmények), az ezekről szóló adatokat három háttérkérdőív segítségével gyüjtik össze (Tanulói, Intézményi és Telephelyi kérdöív).

Elemzésem során három mutatót vizsgáltam. A családiháttér-indexet (CSHI) a Tanulói kérdőív bizonyos kérdéseiből (szülök iskolai végzettsége, otthoni és a tanuló saját könyveinek száma, számítógép a családban) súlyozással számítják ki, várható értéke 0 , szórása 1 . Az egész évfolyamra vett átlaga nagyjából nulla, és ettől az értéktől az egyes tanulókhoz tartozó értékek átlagosan kb. 1-gyel térnek el (vagyis a szórás kb. 1). Egy adott évfolyamra nem számítható egy iskola egy adott telephelyén és képzési típusában (FEH) CSHI-átlag, amennyiben 10 fónél kevesebb tanuló van, illetve ha a tanulók kevesebb mint kétharmada töltötte ki a kérdőívet. Átlagosan 70\%-os kitöltöttségről beszélhetünk.

A halmozottan hátrányos helyzetü $(\mathrm{HHH})$ tanulók arányát pontosan ismerjük minden feladatellátási helyen, ezt az intézmények szolgáltatják a méréstől függetlenül, a kötelező adatszolgáltatás keretében. Halmozottan hátrányos helyzetü az a gyermek, aki rendszeres gyermekvédelmi kedvezményre jogosult, illetve az alábbi három körülményböl legalább kettő fennáll: (1) az együtt nevelő szülők, az egyedül nevelő szülő, vagy a gyám legmagasabb iskolai végzettsége alapfokú; (2) a szülő vagy a gyám foglalkoztatottsága alacsony; (3) elégtelen lakókörnyezet, lakáskörülmény (1997. évi XXXI. törvény (Gyvt.) 67/A. § (2))

A tanulók között a romák arányáról a telephely vezetője tájékoztat a Telephelyi kérdőív kitöltésekor. 
Fontos tudni, hogy a háttérkérdőívek kitöltése (Tanulói, Intézményi és Telephelyi) nem kötelezö, bármely kérdés esetén megtagadható a válaszadás. Az általam használt CSHI- és HHH-arány adatok a 8. évfolyamra vonatkoznak, a tanulói adatokat tartalmazó adatbázisokból (mérési fájlokból) aggregálással (összesítéssel) keletkeztek.

A vizsgált populáció 2010-ben és 2016-ban is az OKM 8. évfolyamra vonatkozó méréséből azok a 2, 3 és 4 feladatellátási hellyel rendelkező települések, ahol 2016-ban volt egyházi iskola. A 2016-ban iskolát fenntartó felekezetek közül azokat választottam ki, amelyeknek tanulói létszáma az évfolyamon meghaladta azt a több százas nagyságrendet, mely esetében már az egész rendszerre gyakorolt hatásokról beszélhetünk, illetve a legtöbb intézménnyel rendelkeztek. Az ilyen felekezetek közül is csak azok szerepelnek a vizsgálatban, amelyeknek volt iskolájuk 2, 3 vagy 4 FEH-es településen. Ezek a Magyar Katolikus Egyház, a Magyar Református Egyház, a Magyarországi Evangélikus Egyház, a Görögkatolikus Metropólia és a Magyarországi Baptista Egyház.

Szeretném hangsúlyozni, hogy a kutatási eredmények, amelyekből következtetéseket tudok levonni, ezen öt felekezetre, a 2010 és 2016 közötti adatok alapján, és olyan képzési programra vonatkoznak, ahol jelen vannak 8. évfolyamos tanulók. Azaz nem jellemzem például a rendszerváltás előtti időszakot, más, nem vizsgált egyházi felekezeteket, vagy a vizsgált felekezetek szakképzésben mutatott viselkedését.

\section{Eredmények}

\section{Feladatellátási helyek}

2016-ban 74 település felelt meg a fentebb sorolt feltételeknek. Ugyanezen települések iskoláit vizsgáltam a 2010-es esztendőre is. Több településen a FEH-ek száma is átrendeződött/racionalizálódott a 2011-2012-es fenntartóváltási hullámot követően (1. ábra).

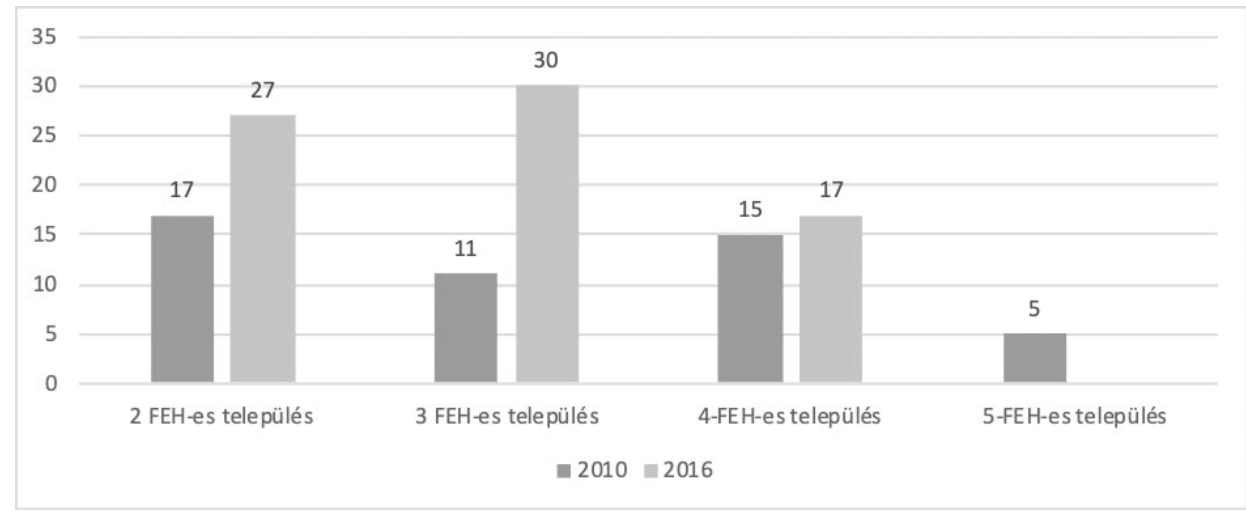

1. ábra. A 2016-ban 2, 3 és 4 FEH-es, egyházi iskolával rendelkezö településeken a települések száma a FEH-ek száma szerint 2010-ben és 2016-ban (forrás: OKM 2010. és 2016. évi 8. évfolyamos adatbázis)

2010-ben a 74 településen összesen 225 FEH volt, ebböl 48 településen 54 egyházi fenntartású, amely az összes iskola 24\%-a. 2016-ban valamivel kevesebb FEH volt (212), az egyházi iskolák száma majdnem megduplázódott, arányuk 43,4\% lett (2. ábra). 


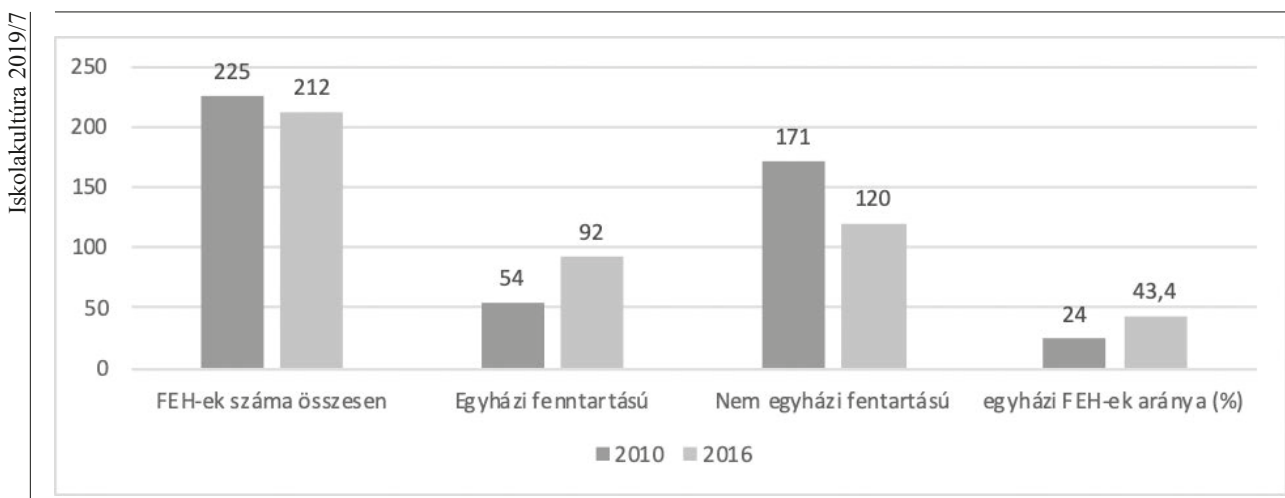

2. ábra. A 2016-ban 2, 3 és 4 FEH-es, egyházi iskolával rendelkezö településeken a FEH-ek száma és aránya 2010-ben és 2016-ban (forrás: OKM 2010. és 2016. évi 8. évfolyamos adatbázis)

A fenntartók jelenlétéről a következőket tudjuk: a vizsgált települések között 2010-ben 26 településen nem volt egyházi fenntartású iskola. 2010 és 2016 között a katolikusok vettek át legnagyobb számban iskolát; 2016-ban 80\%-kal több iskola tartozik hozzájuk, mint 2010-ben. A reformátusokhoz 12 iskola került, így több mint 50\%-kal nőtt az iskoláik száma. Az evangélikusok két iskolával gyarapodtak, a görögkatolikusok a meglévő kettő mellé még hármat vettek át. 2016-ra megjelentek a baptisták mint fenntartók (3. ábra).

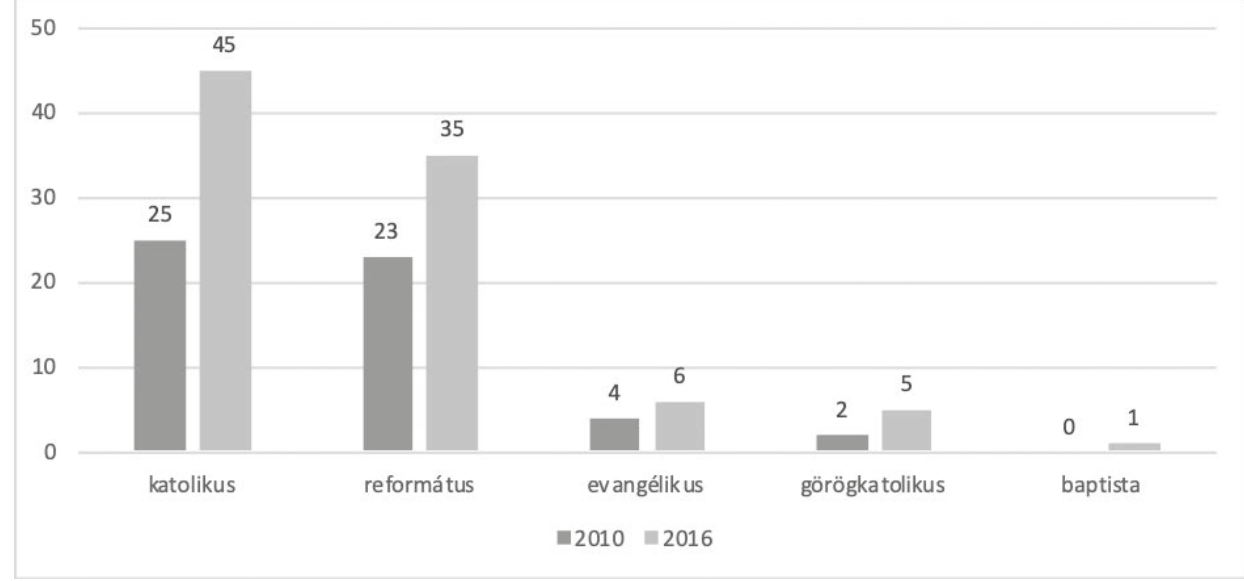

3. ábra. A 2016-ban 2, 3 és 4 FEH-es, egyházi iskolával rendelkezö településeken az egyes felekezetek által fenntartott iskolák száma, ahol volt 8. évfolyam 2010-ben és 2016-ban (forrás: OKM 2010. és 2016. évi 8. évfolyamos adatbázis) 


\section{Családiháttér-index}

Minden beiskolázási körzet/település rendelkezik egy szelekciós struktúrával, már két intézmény esetén is van különbség a CSHI-átlagok között. Ez eddig matematikai valószínüség, de a szelekcióval kapcsolatosan akkor tudjuk értelmezni, látjuk ennek a hatását, ha összevetjük egymással a különböző mutatókat (itt: CSHI-átlagok, HHH- és romaarány). Nézzük meg Nyírbátor példáját (1. táblázat)!

1. táblázat. Nyirbátor szelekciós iskolastruktúrája (forrás: OKM 2016. évi 8. évfolyamos adatbázis)

\begin{tabular}{|c|c|c|c|c|c|}
\hline Iskola & Fenntartó & Iskolatípus & $\begin{array}{l}\text { CSHI } \\
\text { átlag }\end{array}$ & $\begin{array}{c}\text { HHH- } \\
\text { arány (\%) }\end{array}$ & $\begin{array}{c}\text { Roma- } \\
\text { arány (\%) }\end{array}$ \\
\hline $\begin{array}{l}\text { Báthory István } \\
\text { Katolikus Általános } \\
\text { Iskola, Gimnázium } \\
\text { és Szakközépiskola }\end{array}$ & M Katolikus E & $\begin{array}{l}8 \text { évfolyamos } \\
\text { gimnázium }\end{array}$ & 0,22 & 0 & 0 \\
\hline $\begin{array}{l}\text { Nyírbátori } \\
\text { Református } \\
\text { Általános Iskola }\end{array}$ & M Református E & Általános iskola & $-0,45$ & 19,10 & 20 \\
\hline $\begin{array}{l}\text { Nyírbátori Magyar- } \\
\text { Angol Kéttannyelvü } \\
\text { Általános Iskola és } \\
\text { Alapfokú Múvészeti } \\
\text { Iskola }\end{array}$ & Állami IF & Általános iskola & $-0,47$ & 36,80 & 43 \\
\hline
\end{tabular}

Az adatokból kiderül, hogy a 8 évfolyamos katolikus iskola CSHI-átlaga jelentősen magasabb a másik két iskola CSHI-átlagánál, az OKM adatai szerint nincsen sem halmozottan hátrányos helyzetü, sem roma tanulója. A református iskola CSHI-átlaga az állami iskola CSHI-átlagának közelében van, ám csupán feleannyi HHH és roma tanulója van. A szelekciós hierarchia alján lévő állami iskola CSHI-átlaga a legalacsonyabb, tanulóinak több mint harmada halmozottan hátrányos helyzetü, és majdnem a fele roma származású, így definíció szerint erősen gettósodó iskolának tekinthető. Ebben az esetben, figyelembe véve a szélsőséges értékeket, megállapítható, hogy a katolikus iskola kifejezetten szelektál, ami a települési iskolastruktúrára gyakorolt hatását tekintve szegregációt generál.

Elsőként megvizsgáltam, hogy a felekezeti iskolák hány esetben rendelkeznek a legmagasabb és legalacsonyabb CSHI-átlaggal a településen (4. ábra). 


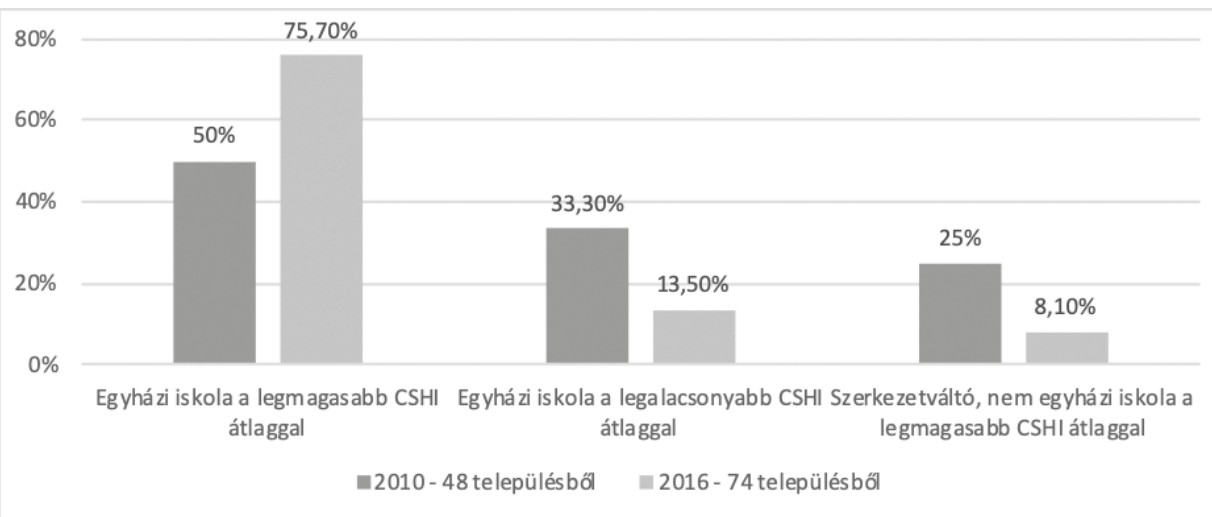

4. ábra. Települések aránya, ahol az egyházi iskolák CSHI-átlaga a legmagasabb, legalacsonyabb, illetve ahol a szerkezetváltó, nem felekezeti iskolák CSHI-átlaga a legmagasabb 2010-ben és 2016-ban (forrás: OKM 2010. és 2016. évi 8. évfolyamos adatbázis)

Szám szerint több mint kétszer annyi településen volt a felekezeti iskola CSHI-átlaga a legmagasabb 2016-ban, mint 2010-ben. Míg 2010-ben a településeknek a fele, 2016-ban a 76\%-a ilyen. Csaknem harmadára csökkent azoknak az iskoláknak az aránya, ahol a legalacsonyabb CSHI-átlag felekezeti fenntartású iskoláé. Fontos tudni, hogy több ilyen esetben (pl. 2010-ben Hajdúdorog, görögkatolikus iskolák; 2016, Jászapáti, katolikus iskolák; 2016, Kisújszállás, református és baptista iskolák) a legmagasabb és a legalacsonyabb CSHI-átlag is egyházi iskoláé volt (ennek okaira később visszatérek).

Tudjuk, hogy a szerkezetváltó, nem egyházi fenntartású iskolák mint a magyar oktatási rendszer évtizedek óta „bevett” szelekciós csatornái erős elszívó hatással rendelkeznek; jellemzően a magas státuszú, középosztálybeli családok gyermekeit gyüjtik össze. 2010 és 2016 között ezeknek az iskoláknak is - melyek CSHI-átlaga a településen a legmagasabb, vagyis családi hátterük a legkedvezőbb - közel harmadára csökkent az arányuk a felekezeti iskolák térnyerésével párhuzamosan.

Az 1. sz. melléklet összefoglaló táblázatából látható, hogy a legmagasabb CSHIátlagokkal rendelkező iskolák hogyan oszlanak meg felekezetek szerint. A katolikus intézmények száma több mint kétszeres, a református iskoláké majdnem háromszoros lett 2016-ra.

Érdemes ezeket az eredményeket úgy is mérlegelni, hogy 2016-ban a 45 katolikus iskolából 27 (60\%) CSHI-átlaga a településen a legmagasabb, csakúgy, mint a 35 református iskolából 21(60\%), az 5 evangélikus iskolából 3 (60\%), az 5 görögkatolikus iskolából $4(80 \%)$, illetve az $1(100 \%)$ baptista iskola esetében. Több esetben (pl. Albertirsa, katolikus és evangélikus iskolák; Heves, református és katolikus iskolák; Mátészalka, katolikus és református iskolák; Nyírbátor, katolikus és református iskolák) a két legmagasabb CSHI-átlaga a településen két különböző felekezeti iskolának van.

De a szelekció mértékét másképpen is felmérhetjük. Kiszámíthatjuk települési iskolákban tanuló nyolcadikosok CSHI-átlagát. Azt vizsgáltam, hogy hány esetben magasabb az egyházi iskola CSHI-átlaga, mint az adott település CSHI-átlaga (5. ábra). 
Ercse Kriszta: Az egyházi fenntartású iskolák és a szelekció, szegregáció kapcsolata

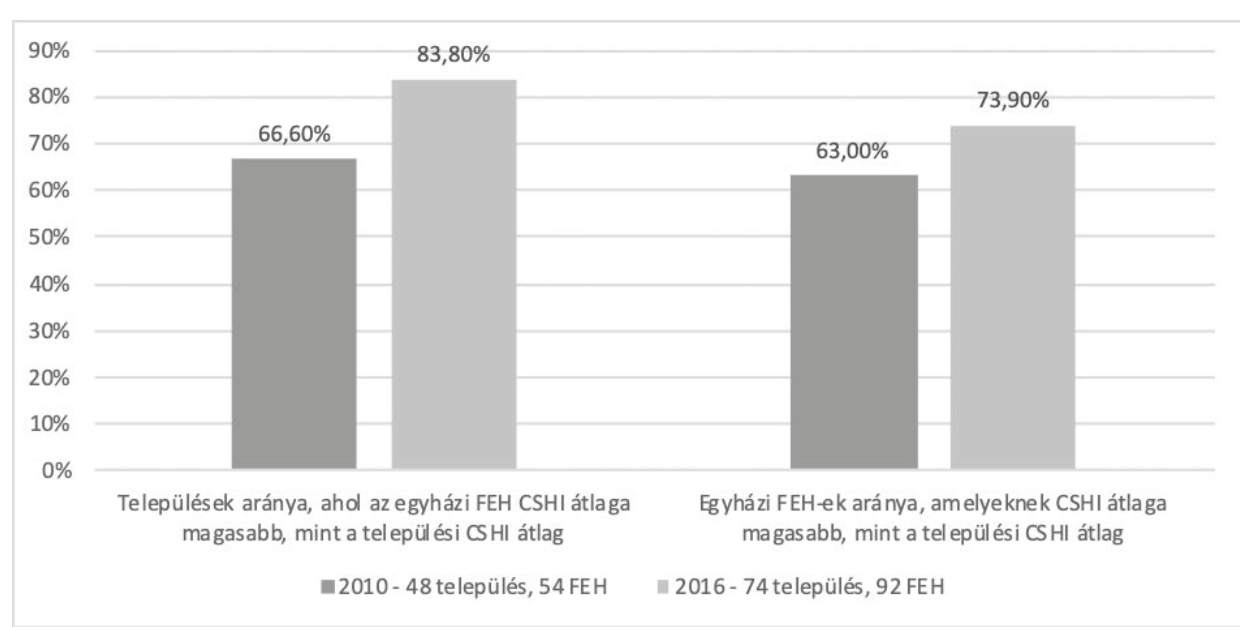

5. ábra. Azon települések aránya, ahol a felekezeti feladatellátó hely CSHI-átlaga magasabb volt a települési CSHI-átlagnál, és ugyanezen FEH-ek aránya 2010-ben és 2016-ban (forrás: OKM 2010. és 2016. évi 8. évfolyamos adatbázis)

Már 2010-ben is a települések kétharmadában a felekezeti iskolák tanulói láthatóan a helyi magasabb státuszú családok gyermekei közül kerültek ki. 2016-ra a felekezeti iskolák tanulói összetételének szocio-ökonómiai felülreprezentáltsága a települések több mint négyötödére jellemző. A 2, 3 és 4 iskolás településeken müködő felekezeti iskoláknak 2010-ben is majdnem a kétharmada, 2016-ra azonban közel háromnegyede a települési CSHI-átlagnál magasabb CSHI-átlagú tanulói közösséggel rendelkezett.

Természetesen az sem mindegy, hogy a települési CSHI-átlag és a felekezeti iskola CSHI-átlaga között mekkora a különbség. A különbségek eloszlása a 2. táblázatban látható. Mivel egy évfolyamon a CSHI-értékek szórása kb. 1, ezért az egy szórásnyi különbség az átlagok között kb. 1, míg a fél szórásnyi különbség kb. 0,5 különbséget jelent. Az index tekintetében már a 0,5-es különbség is jelentősnek számít.

2. táblázat. Települések száma, ahol felekezeti iskolák CSHI-átlaga magasabb, mint a települési CSHI-átlag 2010-ben és 2016-ban, illetve a különbségek mértékének eloszlása (forrás: OKM 2010. és 2016. évi 8. évfolyamos adatbázis)

\begin{tabular}{|l|c|c|}
\hline \multicolumn{1}{|c|}{ Különbség mértéke } & $\mathbf{2 0 1 0}-\mathbf{4 8}$ település & $\mathbf{2 0 1 6}-\mathbf{7 4}$ település \\
\hline Egy szórásnyinál nagyobb & $15(31,25 \%)$ & $17(23 \%)$ \\
\hline Fél szórásnyinál nagyobb & $17(35,4 \%)$ & $38(51,4 \%)$ \\
\hline Fél szórásnyinál kisebb & $16(33,3 \%)$ & $19(25,7 \%)$ \\
\hline
\end{tabular}

2010-ben a települések kétharmadában a felekezeti iskolák CSHI-átlaga nagyobb volt, mint fél szórásnyi, majdnem egyharmadukban nagyobb, mint egy szórásnyi. 2016-ra a települések negyedén a felekezeti iskolák CSHI-átlaga több mint 1 szórásnyival volt a települési átlag felett, és $75 \%$-án a különbség - az egyházi iskola javára - nagyobb volt, mint fél szórásnyi. Azaz kifejezetten nőtt a településen belüli iskolák tanulói közösségeinek szocio-ökonómiai különbsége.

A szelekcióról nem csupán a települési és felekezeti fenntartású iskolák CSHI-átlagának különbsége tájékoztat, érdemes megnézni az iskolai CSHI-átlagok szórását 2010-ben és 2016ban. Minél nagyobb a szórás, annál nagyobb a szelekció az adott településen (3. táblázat). 
3. táblázat. A 74 település CSHI-átlag szórásának átlaga és változása 2010-ben és 2016-ban (forrás: OKM 2010. és 2016. évi 8. évfolyamos adatbázis)

\begin{tabular}{|l|c|c|}
\hline \multicolumn{1}{|c|}{ Indikátor } & $\mathbf{2 0 1 0}$ & $\mathbf{2 0 1 6}$ \\
\hline Szórások átlaga & 0,416 & 0,5056 \\
\hline
\end{tabular}

A szelekció mértéke 2010-ben és 2016-ban is magas volt. Ha a szórások változását nézzük a két vizsgált év között, azt látjuk, hogy 74 településből 39-en nőtt a települési CSHI-átlag szórása - ez 52,7\%-a a településeknek -, vagyis nőtt a szelekció mértéke. 23 településen 2010-ben is volt egyházi fenntartó. Hogy milyen felekezeti fenntartók érintettek, az 1. sz. mellékletben látjuk.

Azoknak a településeknek több mint a felén, ahol a katolikus iskolák jelen vannak, nött a szelekció mértéke, ez a református iskolák és a görögkatolikus iskolák kevesebb mint a felénél van így, az evangélikus iskolák harmadánál. Az egy baptista intézmény is ilyen településen van.

A 2010-es állapot is a szelekció egyértelmü jelenlétét mutatja a településeken. 2016-ra azonban - számban és arányban - a szelekciót jól jelző, településen belüli CSHI-átlagok különbsége (felekezeti FEH vs állami, illetve kisszámú esetben másik felekezeti, ld. például 2016, Felsőzsolca, Nyírbátor) is drasztikusan megnőtt. Azaz több helyen lett az egy településen belüli iskolák tanulói között még nagyobb a családiháttér-alapú különbség.

\section{Halmozottan hátrányos helyzetü tanulók aránya}

$\mathrm{Az}$ is mutatója a településen belüli intézményi szelekciónak, hogy a halmozottan hátrányos helyzetü tanulók mennyire egyenletesen oszlanak el az iskolák között. Az iskolák HHH-arányát vizsgáltam meg, leválogatva azokat a településeket, ahol ez az arány legalább 3\% volt. Fontos információ, hány településen a legalacsonyabb a felekezeti iskola HHH-aránya, illetve a tapasztalatok alapján azt is kell látni, hogy számos helyen egyáltalán nincs HHH tanuló az egyházi iskolákban (6. ábra).

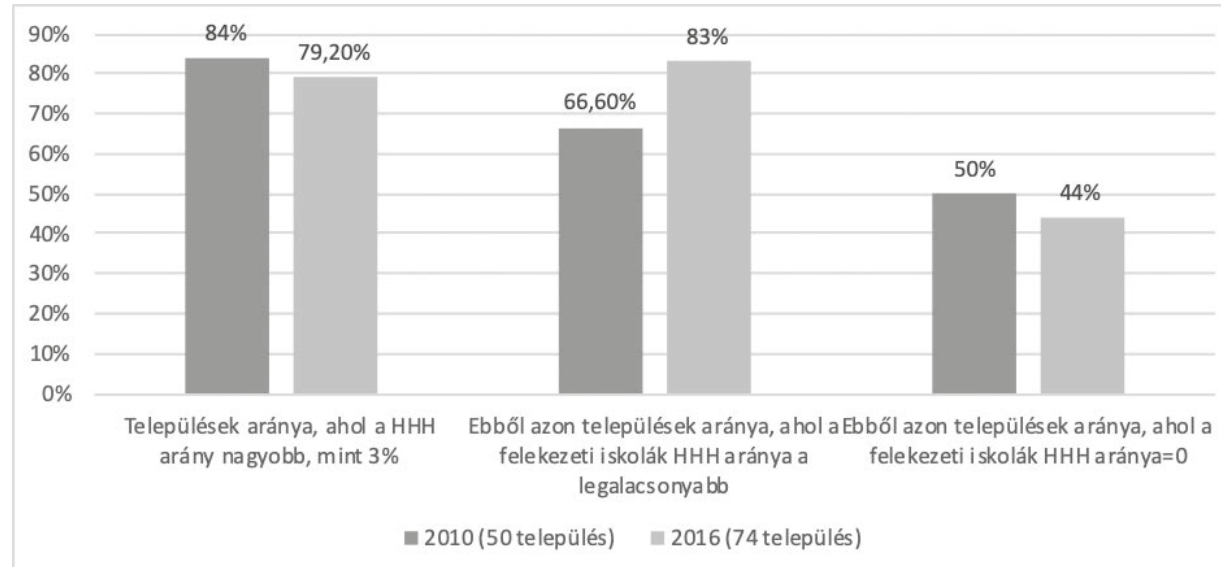

6. ábra. Települések aránya, ahol a HHH-arány legalább 3\%, illetve ahol a felekezeti iskolák HHH-aránya a legalacsonyabb, és ahol a felekezeti iskolák HHH-aránya nulla 2010-ben és 2016-ban (forrás: OKM 2010. és 2016. évi 8. évfolyamos adatbázis) 
Jól látható, hogy a településeknek nagyjából a négyötödére jellemző, hogy 3\%-nál több HHH tanuló van. Az ilyen települések száma 2016-ra 17-tel nőtt. Már 2010-ben is az esetek kétharmadában az egyházi iskolák tanulói között volt a legkisebb a halmozottan hátrányos diákok aránya, de 2016-ra ez a települések 83\%-ában volt így. 2010-ben ezen települések felénél, 2016-ban majdnem a felénél - bár az ilyen iskolák száma tovább nőtt - az egyházi iskolákban nem volt HHH tanuló. Ugyanezeket az adatokat felekezetekre bontva láthatjuk az 1. sz. mellékletben, és azt is, hogy hogyan aránylik ez a szám az egyes felekezetek összes, a kutatásban szereplő iskoláihoz.

Már 2010-ben a katolikus és református iskolák nagyjából felében a HHH tanulók aránya a legkisebb volt az adott településen. 2016-ra különösen az olyan katolikus és református fenntartású iskolák száma nőtt meg (majdnem megduplázódott), ahová a településen a legkevesebb halmozottan hátrányos helyzetü tanuló jár. Azon iskoláik száma is nőtt, ahová egyáltalán nem jár HHH-s tanuló - és ezzel nőtt az olyan települések száma is, ahol teljes intézményes szeparáció valósult meg. Az evangélikus fenntartású iskolák száma mind a két kérdéses területen csökkent, a görögkatolikus iskolák száma nőtt az olyan településeken, ahol e felekezet iskoláiban volt a legalacsonyabb a HHH-arány. Tudnunk kell, hogy a nullás HHH-arány egy szélsőséges érték, és bár már ez is megdöbbentő eredményt mutat, e tanulók szeparációja ennél is erőteljesebb: számos olyan település van, ahol a felekezeti iskola $\mathrm{HHH}$-aránya nem a legalacsonyabb, de a települési iskolastruktúrában e mutató viszonyai szélsőségesen alakulnak, ahogy - a példa kedvéért - Gyomaendrődön is látható (4. táblázat).

4. táblázat. Gyomaendröd szelekciós iskolastruktúrája 2010-ben (forrás: OKM 2010. évi 8. évfolyamos adatbázis)

\begin{tabular}{|l|l|c|c|c|}
\hline Fenntartó & Iskolatípus & CSHI-átlag & HHH-arány (\%) & Romaarány (\%) \\
\hline Önkormányzat & Általános iskola & 0,16 & 2,9 & 12 \\
\hline Önkormányzat & Általános iskola & $-0,34$ & 26,1 & 40 \\
\hline Önkormányzat & Általános iskola & na & 50 & 62 \\
\hline M Katolikus E & Általános iskola & 0,34 & 4,5 & 25 \\
\hline
\end{tabular}

A katolikus iskola HHH-arányához képest a másik két állami települési iskola HHH-aránya több mint hatszoros, illetve több mint tízszeres. Ezzel párhuzamosan látni kell azt is, hogy amíg a katolikus iskola roma tanulói aránya $25 \%$, addig az előbb említett két állami iskolában ez majdnem kétszeres, illetve több mint kétszeres - gettósodó (tehát a roma tanulók aránya $30 \%<>50 \%$ ) és gettóiskolák (roma tanulók aránya $>50 \%$ ).

\section{Romaarány}

A roma tanulók arányát hasonló módon vizsgáltam, ebben az esetben azokon a településeken, ahol a romaarány elérte az 5\%-ot. 2010-ben 43 ilyen település volt (a 48 településböl, ahol volt egyházi fenntartó), 2016-ban 65 (74 településböl). Amellett, hogy megnéztem, hány településen a legalacsonyabb az egyházi iskola romaaránya, és hány településen nulla, azt is fontosnak tartottam felmérni, hogy hány településen nem szolgáltatott ilyen adatot az intézmény (5. táblázat). 
5. táblázat. Települések száma-aránya, ahol van egyházi fenntartó, a tanulói romaarány legalább 5\%, felekezeti iskolák száma-aránya, ahol a romaarány legalacsonyabb, vagy nincs, vagy nem szolgáltatott adatot 2010-ben és 2016-ban (forrás: OKM 2010. és 2016. évi 8. évfolyamos adatbázis)

\begin{tabular}{|l|c|c|}
\hline \multicolumn{1}{|c|}{ Indikátorok } & $\mathbf{2 0 1 0 ~ ( 4 8 ~ t e l e p u ̈ l e ́ s ) ~}$ & $\mathbf{2 0 1 6}$ (74 település) \\
\hline Ahol a tanulói romaarány nagyobb, mint 5\% & $48 / 43(89,6 \%)$ & $74 / 65(87,8 \%)$ \\
\hline $\begin{array}{l}\text { Ebből a felekezeti iskolák romaaránya a } \\
\text { legalacsonyabb }\end{array}$ & $43 / 26(60,5 \%)$ & $65 / 46(70,8 \%)$ \\
\hline Ebből a felekezeti iskolák romaaránya nulla & $43 / 2(4,7 \%)$ & $65 / 13(20 \%)$ \\
\hline $\begin{array}{l}\text { Ahol az egyházi iskola nem szolgáltatott } \\
\text { adatot }\end{array}$ & $43 / 8(18,6 \%)$ & $65 / 15(23 \%)$ \\
\hline
\end{tabular}

Már 2010-ben is a felekezeti iskoláknak jóval több mint a fele a legalacsonyabb romaaránnyal rendelkezett a településen. Két egyházi intézményben nem voltak roma tanulók, ám az iskoláknak majdnem az ötöde nem jelentett ilyen adatot. 2016-ra majdnem megduplázódott azon felekezeti iskolák száma, ahol a településen a legkisebb volt a romaarány, ez a települések $70 \%$-át jelenti. 2016-ra majdnem hétszer annyi iskolában egyáltalán nem voltak jelen roma tanulók, így a települések egyötödében megvalósult a totális etnikai szelekció. Megduplázódott azon intézmények száma is, amelyek nem szolgáltattak adatot arról, milyen arányban vannak roma tanulóik. Hangsúlyozom, olyan településekről van szó, ahol vannak roma tanulók. Nézzük meg ugyanezt felekezeti bontásban a 12. táblázatban.

Mind 2010-ben, mind 2016-ban a református fenntartású iskolák rendelkeztek a legnagyobb számban a legalacsonyabb romaaránnyal településükön belül, 2010-ben és 2016-ban is iskoláiknak majdnem a két-

Már 2010-ben is a felekezeti iskoláknak jóval több mint a fele a legalacsonyabb romaaránnyal rendelkezett a településen. Két egyházi intézményben nem voltak roma tanulók, ám az iskoláknak majdnem az ötöde nem jelentett ilyen adatot. 2016-ra majdnem megduplázódott azon felekezeti iskolák száma, ahol a településen a legkisebb volt a romaarány, ez a települések 70\%-át jelenti. 2016ra majdnem hétszer annyi iskolában egyáltalán nem voltak jelen roma tanulók, így a települések egyötödében megvalósult a totális etnikai szelekció. harmada tartozott ide. 2010-ben a katolikus iskolák jóval több mint egyharmadában, majd 2016-ra számuk megkétszereződött, így majdnem a felében volt a településen a legkisebb arányban roma tanuló. 2016-ban a református iskolák $20 \%$-ában, a katolikus iskolák több mint 10\%-ában egyáltalán nem volt roma tanuló. Több mint kétszer annyi intézményük nem szolgáltatott erre vonatkozó adatot. 2016-ra eggyel több evangélikus iskolától nem érkezett adat, a görögkatolikus képzési programok $60 \%$-ában a településen a legalacsonyabb volt a roma tanulók aránya, illetve náluk is nőtt az adatot nem szolgáltató iskolák száma.

Az esetek elenyésző kisebbségében alakult viszonylag egyenletesen a roma tanulók eloszlása, ahogyan például 2010-ben Móron (romaarányok: 4\%, 5\% és 6\% - felekezeti), Sárváron (4\% - felekezeti, 5\%, 6\%), vagy 2016-ban Albertirsán (3\% - felekezeti, 4\% felekezeti, 5\%). Megnéztem a gettósodó és gettóiskolák számát 2010-ben és 2016-ban azokon a településeken, ahol volt egyházi fenntartó. A táblázatból azonnal látszik, hogy a roma tanulók szegregációjának mértéke, mely már 2010-ben is nagyon magas volt, 
döbbenetes mértékben növekedett. 2010-ben a települések 38\%-án volt gettósodó vagy gettóiskola, 2016-ban majdnem minden második településen (6. táblázat).

6. táblázat. Gettósodó és gettóiskolákkal kapcsolatos adatok azokon a településeken, ahol 2010-ben volt egyházi fenntartó, 2010-ben és 2016-ban (forrás: OKM 2010. és 2016. évi 8. évfolyamos adatbázis)

\begin{tabular}{|c|c|c|}
\hline & $2010-48$ település & 2016 - 74 település \\
\hline $\begin{array}{l}\text { Érintett települések száma } \\
\text { (aránya az összeshez képest, \%) }\end{array}$ & $19(38,8)$ & $34(45,9)$ \\
\hline $\begin{array}{l}\text { FEH-ek száma - ebből gettó vagy } \\
\text { gettósodó (aránya az összeshez képest, \%) }\end{array}$ & $68-22(32,4)$ & $97-42(43,3)$ \\
\hline Gettósodó iskolák száma & 13 & 17 \\
\hline Gettóiskolák száma & 9 & 25 \\
\hline \multirow{4}{*}{ Fenntartók } & 18 önkormányzati & 34 állami \\
\hline & 1 katolikus & 6 katolikus \\
\hline & 2 református & 1 református \\
\hline & 1 alapítvány & 1 iszlám \\
\hline \multirow{6}{*}{ Nem szolgáltatott adatot } & 10 & 10 \\
\hline & $\begin{array}{l}4 \text { önkormányzati } \\
\text { általános iskola }\end{array}$ & $\begin{array}{l}2 \text { állami } \\
\text { szerkezetváltó }\end{array}$ \\
\hline & $\begin{array}{l}4 \text { önkormányzati } \\
\text { szerkezetváltó } \\
1 \text { katolikus általános } \\
\text { iskola }\end{array}$ & $\begin{array}{l}1 \text { katolikus általános } \\
\text { iskola }\end{array}$ \\
\hline & $\begin{array}{l}1 \text { református } \\
\text { szerkezetváltó }\end{array}$ & $\begin{array}{l}4 \text { katolikus } \\
\text { szerkezetváltó }\end{array}$ \\
\hline & & $\begin{array}{l}1 \text { református ált. } \\
\text { iskola }\end{array}$ \\
\hline & & $\begin{array}{l}2 \text { református } \\
\text { szerkezetváltó }\end{array}$ \\
\hline
\end{tabular}

Hajszál híján megduplázódott az érintett intézmények száma. Több lett a gettósodó iskola is, de a gettóiskolák száma majdnem háromszoros lett. A szegregáció eredetének szempontjából több mint beszédes, hogy a gettósodó és gettóiskolák fenntartói mind a két vizsgált évben több mint az esetek $80 \%$-ában az önkormányzat vagy az állam. Az egy településen/iskolastruktúrán belüli dinamikákat figyelembe véve ez azt jelenti, hogy a felekezeti iskolák szelekciója beszorítja a roma gyerekeket az állami iskolákba. Fontos tudni, hogy felekezet több esetben úgy fenntartója gettósodó iskolának, hogy a településen csak gettósodó vagy gettóiskola van (és a felekezeti iskoláé a kedvezőbb arány). Mindezt felekezeti bontásban láthatjuk a 12. táblázatban.

2010-ben a katolikus iskoláknak több mint a harmada, a református iskoláknak majdnem a fele olyan településen volt, ahol kialakult a roma tanulók szegregációjának szélsőséges formája. 2016-ra ez az állapot rosszabb lett; a katolikus iskolák majdnem fele ilyen településen volt, s ebben a körben nött a református iskolák száma is. 2016-ra 
azon a településen is szélsőségesen egyenlőtlenné vált a roma tanulók eloszlása, ahol az evangélikus felekezet tartott fenn iskolát. Azon a két településen, ahol a görögkatolikus egyház 2016-ban megjelent, már 2010-ben is volt gettó- vagy gettósodó iskola - a felekezet nem azokat vette át.

\section{Felekezetiiskola-hatás}

A fenti számok tükrében is nehéz lenne vitatni a felekezeti iskolák szerepét a települési szegregáció kialakulásában és fennmaradásában, de talán még egyértelmübb képet kapunk ezekröl a folyamatokról, ha azt a 26 települést vesszük szemügyre, ahol 2010-ben nem volt egyházi fenntartó. Nézzük meg ugyanezeket az adatokat (7. táblázat).

7. táblázat. Gettósodó és gettóiskolákra vonatkozó adatok azokon a településeken, ahol 2010-ben nem volt egyházi fenntartó, 2010-ben és 2016-ban (forrás: OKM 2010. és 2016. évi 8. évfolyamos adatbázis)

\begin{tabular}{|c|c|c|}
\hline Indikátorok & $2010-26$ település & $2016-26$ település \\
\hline $\begin{array}{l}\text { FEH-ek száma - ebből gettó vagy } \\
\text { gettósodó (aránya az összeshez } \\
\text { képest \%) }\end{array}$ & $73-17(23,3)$ & $75-21(28)$ \\
\hline Gettósodó iskolák száma & 7 & 8 \\
\hline Gettóiskolák száma & 10 & 13 \\
\hline \multirow{3}{*}{ Fenntartók } & \multirow{3}{*}{17 önkormányzat } & 17 állami \\
\hline & & 3 katolikus \\
\hline & & 1 iszlám \\
\hline \multirow{6}{*}{ Nem szolgáltatott adatot } & 16 & 8 \\
\hline & 11 általános iskola & 2 állami szerkezetváltó \\
\hline & 5 szerkezetváltó & 1 katolikus általános iskola \\
\hline & & 3 katolikus szerkezetváltó \\
\hline & & 1 református szerkezetváltó \\
\hline & & $\begin{array}{l}1 \text { evangélikus } \\
\text { szerkezetváltó }\end{array}$ \\
\hline
\end{tabular}

Ezen települések esetében is látszik, hogy nőtt a szegregáló intézmények száma, a gettóiskolák száma nőtt jobban. 2016-ban ezeknek az iskoláknak a fenntartója ugyancsak 80\%-ban az állam, a fennmaradó 4 esetben két településen (Jászapáti és Jászladány) mind a két iskola gettó vagy gettósodó, és az arányokat nézve (40:95, 40:99) a katolikus iskoláké az alacsonyabb. A harmadik településen (Felsőzsolca) egy katolikus iskola van $99 \%$, és egy református $11 \%$ roma aránnyal.

Amennyiben a településeken az intézményi CSHI-átlagok szórásának segítségével is szeretnénk megnézni a szelekció mértékének alakulását, azt találjuk, hogy a 26 településből 15 esetében nőtt a szórás, azaz nőtt a szelekció is. Ezt felekezetenként a 8. táblázat mutatja. 
Ercse Kriszta: Az egyházi fenntartású iskolák és a szelekció, szegregáció kapcsolata

8. táblázat. Egyházi FEH-ek száma településeken, ahol 2010-ben nem volt egyházi fenntartó, és nött a települési CSHI-átlag szórása (forrás: OKM 2010. és 2016. évi 8. évfolyamos adatbázis)

\begin{tabular}{|l|c|}
\hline $\begin{array}{c}\text { Felekezeti FEH-ek száma településeken*, ahol } \\
\text { 2010-ben nem volt egyházi fenntartó, és nőtt a } \\
\text { települési CSHI-átlag szórása }\end{array}$ & $\begin{array}{c}\text { 2010-2016 között nőtt a települési } \\
\text { CSHI-átlag szórása }\end{array}$ \\
\hline katolikus & 12 \\
\hline református & 6 \\
\hline evangélikus & 0 \\
\hline görögkatolikus & 2 \\
\hline baptista & 0 \\
\hline
\end{tabular}

* 5 településen 2 egyházi fenntartású iskola van

A 2010-ben egyiskolás települések esetén, ahol nem volt egyházi fenntartó (Átány, Biharkeresztes, Felsőzsolca), azt láthatjuk a 2016-os CSHI-átlag szórás-értéke segítségével, hogy a felekezeti iskola és az állami iskola CSHI-átlaga között egy szórásnyinál jóval nagyobb a különbség. Ezeket a településeket is ide soroltam, mert az egyházi iskola belépésével az egy iskola 2010-es CSHI-átlagához képest 2016-ra szélsőséges értékeket vett fel a két iskola 2016-os CSHI-átlaga, és a szórásuk is extrém nagy.

Ami viszont igazán világosan mutatja a felekezeti iskolák hatását a települési szelekciós struktúrákra, az azoknak a településeknek a helyzete, amelyeken 2010-ben nem volt egyházi fenntartó, nem volt sem gettósodó, sem gettóiskola (9. táblázat).

9. táblázat. Települések adatai, ahol 2010-ben csak önkormányzat volt fenntartó, nem volt gettósodó vagy gettóiskola, 2010-ben és 2016-ban (forrás: OKM 2010. és 2016. évi 8. évfolyamos adatbázis)

\begin{tabular}{|c|c|c|c|c|c|c|c|c|c|}
\hline \multirow[b]{2}{*}{ Település } & \multicolumn{4}{|c|}{2010} & \multicolumn{5}{|c|}{2016} \\
\hline & Iskolatípus & $\begin{array}{l}\text { CSHI- } \\
\text { átlag }\end{array}$ & $\begin{array}{c}\mathrm{HHH}, \\
\%\end{array}$ & $\begin{array}{c}\text { Roma, } \\
\%\end{array}$ & Fenntartó & Iskolatípus & $\begin{array}{l}\text { CSHI- } \\
\text { átlag }\end{array}$ & $\begin{array}{c}\mathrm{HHH}, \\
\%\end{array}$ & $\begin{array}{c}\text { Roma, } \\
\%\end{array}$ \\
\hline \multirow{4}{*}{$\begin{array}{l}\text { Bátony- } \\
\text { terenye }\end{array}$} & Ált. iskola & 0,4 & 0 & na & Állami IF & Ált. iskola & -1 & 23,7 & 40 \\
\hline & 6 évf. gimn. & 0,07 & 8,3 & na & Állami IF & Ált. iskola & -1 & 23,3 & 30 \\
\hline & Ált. iskola & $-0,5$ & 9,1 & 0 & M Katolikus E & Ált. iskola & 0,2 & 4,2 & 6 \\
\hline & Ált. iskola & $-0,5$ & 16,4 & 19 & & & & & \\
\hline \multirow{2}{*}{$\begin{array}{l}\text { Bihar- } \\
\text { keresztes }\end{array}$} & Ált. iskola & $-0,3$ & 16,3 & 0 & M Református E & Ált. iskola & 0 & 0 & 0 \\
\hline & & & & & Állami IF & Ált. iskola & -1 & 35,3 & 80 \\
\hline \multirow[t]{4}{*}{ Encs } & Ált. iskola & $-0,1$ & 7,3 & 23 & Állami IF & Ált. iskola & -2 & 100 & 100 \\
\hline & Ált. iskola & $-0,2$ & 7,7 & 26 & Állami IF & Ált. iskola & -2 & 33,3 & 47 \\
\hline & & & & & Állami IF & 6 évf. gimn. & 0 & 7,4 & na \\
\hline & & & & & M Katolikus E & Ált. iskola & 0 & 4,9 & 2 \\
\hline \multirow[t]{2}{*}{ Nagykáta } & Ált. iskola & 0,06 & 4 & 11 & Állami IF & Ált. iskola & -1 & 0 & 50 \\
\hline & Ált. iskola & $-0,5$ & 8,3 & 20 & M Katolikus E & Ált. iskola & 0,1 & 3,8 & 4 \\
\hline
\end{tabular}




\begin{tabular}{|c|c|c|c|c|c|c|c|c|c|}
\hline \multirow[b]{2}{*}{ Település } & \multicolumn{4}{|c|}{2010} & \multicolumn{5}{|c|}{2016} \\
\hline & Iskolatípus & $\begin{array}{l}\text { CSHI- } \\
\text { átlag }\end{array}$ & $\begin{array}{c}\mathrm{HHH}, \\
\%\end{array}$ & $\begin{array}{c}\text { Roma, } \\
\%\end{array}$ & Fenntartó & Iskolatípus & $\begin{array}{l}\text { CSHI- } \\
\text { átlag }\end{array}$ & $\begin{array}{c}\mathrm{HHH}, \\
\%\end{array}$ & $\begin{array}{c}\text { Roma, } \\
\%\end{array}$ \\
\hline \multirow[t]{2}{*}{ Szécsény } & 8 évf. gimn. & 0,08 & 2,1 & na & Állami IF & Ált. iskola & -1 & 31,8 & 55 \\
\hline & Ált. iskola & $-0,1$ & 9,9 & 24 & M Katolikus E & Ált. iskola & 0,2 & 1,8 & 12 \\
\hline \multirow[t]{3}{*}{ Tamási } & 8 évf. gimn. & 0,23 & 7,1 & 28 & Állami IF & Ált. iskola & -1 & 9,1 & 30 \\
\hline & Ált. iskola & $-0,1$ & 11,6 & 10 & M Katolikus E & $\begin{array}{l}8 \text { évf. } \\
\text { gimnázium }\end{array}$ & 0,2 & 0 & na \\
\hline & Ált. iskola & $-0,4$ & 25 & na & & & & & \\
\hline
\end{tabular}

Egy iskola hatását értelemszerűen az adott település vagy beiskolázási körzet iskolastruktúrájának a vizsgálatával lehet kimutatni. Érdemes mind a három mutató változását figyelni a település minden iskolájánál Látszik, ahogyan 2010-hez képest a 2016-ban már különböző fenntartókhoz tartozó iskolák CSHI-átlaga közötti különbség szélsőségesen polarizálódott, ugyanígy megfigyelhető a HHH-tanulók iskolák közötti eloszlásának durván növekvő egyenetlensége. Végül a roma tanulók arányszámai önmagukért beszélnek: azokon a településeken, ahol 2010-ben nem volt egyházi fenntartó, és nem voltak gettó- vagy gettósodó iskolák, a fenntartóváltást követően 2016-ra mindegyik település érintetté vált a szélsőséges roma szegregációban. Kétségtelen, hogy 2010-ben a 6 település 14 iskolájából 4 esetében nem rendelkezünk adattal a romaarányról (ez 3 települést érint), így lehetne úgy érvelni, ezek a települések az etnikai alapú szelekció szempontjából esetleg már akkor a 2016-hoz hasonló állapotban voltak. Egyrészt az érintett iskolák CSHI-átlagai nem ezt sugallják, másrészt más módon is tudunk bizonyosságot szerezni a településre belépő felekezeti iskolák hatásáról. 2010-ben minden iskolának van CSHI-átlaga, így elegendő megnézni, hogy a 2010-es és 2016-os települési CSHI-átlag szórása hogyan változott (10. táblázat). Amennyiben nőtt, akkor nőtt a településen a szelekció mértéke is.
Egy iskola hatását értelemsze-

rúen az adott település vagy beiskolázási körzet iskolastruktúrájának a vizsgálatával lehet kimutatni. Érdemes mind a

három mutató változását figyelni a település minden iskolájánál Látszik, ahogyan 2010hez képest a 2016-ban már különbözó fenntartókhoz tartozó iskolák CSHI-átlaga közötti különbség szélsôségesen polarizálódott, ugyanígy megfigyelhetố a HHH-tanulók iskolák közötti eloszlásának durván növekvố egyenetlensége. Végül a roma tanulók arányszámai önmagukért beszélnek: azokon a településeken, ahol 2010-ben nem volt egyházi fenntartó, és nem voltak gettó- vagy gettósodó iskolák, a fenntartóváltást követóen 2016-ra mindegyik település érintetté vált a szélsốséges roma szegregációban. 
Ercse Kriszta: Az egyházi fenntartású iskolák és a szelekció, szegregáció kapcsolata

10. táblázat. Azon települések CSHI-átlagának szórása 2010-ben és 2016-ban, melyeken 2010-ben nem volt egyházi fenntartó, és nem volt gettó- vagy gettósodó iskola (forrás: OKM 2010. és 2016. évi 8. évfolyamos adatbázis)

\begin{tabular}{|l|c|c|}
\hline Település & $\begin{array}{c}\text { 2010-ben a település } \\
\text { CSHI-átlagának szórása }\end{array}$ & $\begin{array}{c}\text { 2016-ban a település } \\
\text { CSHI-átlagának szórása }\end{array}$ \\
\hline Bátonyterenye & 0,46 & 0,6 \\
\hline Biharkeresztes & - & 0,6 \\
\hline Encs & 0,13 & 0,99 \\
\hline Nagykáta & 0,4 & 0,55 \\
\hline Szécsény & 0,12 & 0,65 \\
\hline Tamási & 0,34 & 0,51 \\
\hline
\end{tabular}

Azt látjuk, hogy 6 településböl 5-ön nőtt a szórás, vagyis a felekezeti iskolák belépésével növekedett a szelekció mértéke. Biharkeresztes esetében nincs CSHI-átlag szórásunk, mert 2010-ben csak egy iskolája volt a településnek. Az azonban, hogy a református iskola létrejötte milyen települési szelekciós struktúrát állított be, a 17. táblázatból jól látszik, mint ahogy az is, hogy a két iskola CSHI-átlaga között több mint egy szórásnyi a különbség.

A felekezeti iskolák tanulói közösségét láthatóan a település magasabb státuszú családjainak gyermekei alkotják, a halmozottan hátrányos helyzetủ és a roma tanulók az állami iskolákba szorulnak, ezzel megindítva és fenntartva egy szegregációs spirált.

\section{Kettős mérce? - szerkezetváltó képzési programok}

Az állami rendszerben már nyilvánvaló, hogy a szerkezetváltó - 6 és 8 évfolyamos gimnáziumok célközönsége és haszonélvezői a magas státuszú családok. A kérdés az, hogy a felekezeti fenntartók érvényesítenek-e hasonló megfontolásokat abban az esetben, ha maguk egy településen kétféle képzési programot is kínálnak: egy általános iskolait, és egy szerkezetváltót.

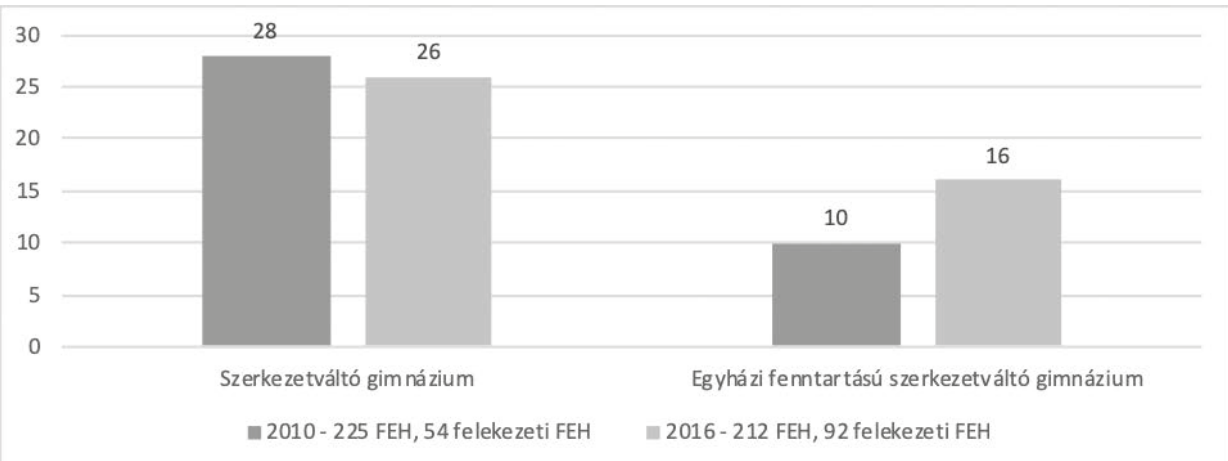

7. ábra. Szerkezetváltó képzési programok 2010-ben és 2016-ban a 2, 3 és 4 FEH-es településeken, ahol 2016-ban volt egyházi iskolafenntartó (forrás: OKM 2010. és 2016. évi 8. évfolyamos adatbázis)

Ahogyan az a 7. ábrán is látszik, mind a két vizsgált évben a felekezeti iskolák nagyjából 18\%-a szerkezetváltó képzést kínál (6 vagy 8 évfolyamos gimnázium). Olyan település, ahol egyszerre van jelen kétféle képzési programmal ugyanaz a fenntartó, 2010-ben 4 volt, 2016ban pedig 7 (11. táblázat). 2010-ben ebben a körben 1 katolikus, 2 református, 1 görögkatolikus fenntartó van, 2016-ban 3 katolikus, 2 református, 1 evangélikus és 1 görögkatolikus. 


\begin{tabular}{|c|c|c|c|c|c|}
\hline \multicolumn{6}{|c|}{$\begin{array}{l}\text { 11. táblázat. Települések, ahol a felekezeti fenntartónak általános iskolai és szerkezetváltó gimnáziumi } \\
\text { (6 vagy 8 évfolyamos) képzése is van 2010-ben és 2016-ban } \\
\text { (forrás: OKM 2010. és 2016. évi 8. évfolyamos adatbázis) }\end{array}$} \\
\hline \multicolumn{6}{|c|}{2010} \\
\hline Település & Fenntartó & Típus & CSHI & HHH-arány & Romaarány \\
\hline \multirow[t]{3}{*}{ Hajdúdorog } & Önkorm. & Ált. iskola & $-0,15$ & 20,3 & 10 \\
\hline & görögkatolikus & Ált. iskola & $-0,43$ & 0 & 3 \\
\hline & görögkatolikus & 6 évf. gimnázium & 0,58 & 6,3 & na \\
\hline \multirow[t]{3}{*}{ Kunszentmiklós } & Önkorm. & Ált. iskola & $-0,6$ & 28,3 & 35 \\
\hline & református & Ált. iskola & 0,22 & 0 & 3 \\
\hline & református & 8 évf. gimnázium & 0,68 & 0 & 3 \\
\hline \multirow[t]{4}{*}{ Piliscsaba } & katolikus & Ált. iskola & 0,73 & 0 & 1 \\
\hline & katolikus & 8 évf. gimnázium & 1,51 & 0 & 1 \\
\hline & Önkorm. & Ált. iskola & 0,29 & 0 & 20 \\
\hline & alapítvány & Ált. iskola & $-0,96$ & 20 & 70 \\
\hline \multirow[t]{5}{*}{ Tiszakécske } & református & Ált. iskola & $-0,71$ & 0 & 5 \\
\hline & református & 6 évf. gimnázium & 0,16 & 0 & 5 \\
\hline & Önkorm. & Ált. iskola & $-0,69$ & 14,3 & 0 \\
\hline & Önkorm. & Ált. iskola & 0,03 & 2,9 & 3 \\
\hline & Önkorm. & Ált. iskola & na & 0 & 30 \\
\hline \multicolumn{6}{|c|}{2016} \\
\hline Település & Fenntartó & Típus & CSHI & HHH-arány & Romaarány \\
\hline \multirow[t]{3}{*}{ Hajdúdorog } & állami & Ált. iskola & $-0,84$ & 22,2 & 15 \\
\hline & görögkatolikus & Ált. iskola & $-0,06$ & 13 & 1 \\
\hline & görögkatolikus & 6 évf. gimnázium & 0,35 & 0 & na \\
\hline \multirow[t]{3}{*}{ Jászapáti } & állami & Ált. iskola & $-0,84$ & 37,2 & 40 \\
\hline & katolikus & Ált. iskola & $-1,79$ & 50 & 95 \\
\hline & katolikus & 8 évf. gimnázium & 0,13 & 5 & na \\
\hline \multirow[t]{3}{*}{ Kiskőrös } & állami & Ált. iskola & $-0,41$ & 1,5 & 25 \\
\hline & evangélikus & 6 évf. gimnázium & 0,56 & 0 & na \\
\hline & evangélikus & Ált. iskola & $-0,14$ & 1,8 & 4 \\
\hline \multirow[t]{3}{*}{ Kunszentmiklós } & állami & Ált. iskola & $-0,65$ & 6,1 & 40 \\
\hline & református & Ált. iskola & 0,01 & 4,5 & 3 \\
\hline & református & 8 évf. gimnázium & 0,51 & 0 & 3 \\
\hline \multirow[t]{3}{*}{ Mezőcsát } & református & Ált. iskola & 0,1 & 4,8 & 10 \\
\hline & református & 6 évf. gimnázium & $-0,25$ & 27,3 & na \\
\hline & állami & Ált. iskola & $-1,43$ & 27,3 & 51 \\
\hline \multirow[t]{4}{*}{ Piliscsaba } & állami & Ált. iskola & $-1,35$ & 14,3 & 60 \\
\hline & állami & Ált. iskola & 0,03 & 0 & 10 \\
\hline & katolikus & Ált. iskola & 0,4 & 0 & na \\
\hline & katolikus & 8 évf. gimnázium & 1,65 & 0 & na \\
\hline \multirow[t]{3}{*}{ Szerencs } & katolikus & 6 évf. gimnázium & 0,4 & 4,8 & na \\
\hline & katolikus & Ált. iskola & $-0,37$ & 3,4 & 0 \\
\hline & református & Ált. iskola & 0,3 & 2,1 & 3 \\
\hline
\end{tabular}


Az eddig vizsgált szempontok szerint a következő olvasható ki a táblázatból: mind a két évben a szerkezetváltó képzés CSHI-átlaga a településen a legmagasabb. 2010-ben két településen több mint két szórásnyival tér el a felekezet általános iskolai képzésének CSHI-átlagától, a másik kettőn pedig több mint fél szórásnyival. 2016-ban Mezőcsát kivételével - ahol nincs fél szórásnyi különbség és az általános iskolai CSHI-átlag a magasabb - nagyon magas a különbség: 3 településen 1 szórásnyi körül van, Kiskőrösön másfélszeres, Jászapátiban kétszeres, Hajdúdorogon több mint fél szórásnyi. A HHH tanulók aránya 2010-ben 4 településből 3 esetében, 2016-ban 7-ből 4 szerkezetváltó képzés esetén nulla, a felekezeti általános iskola HHH-aránya is inkább nulla (2010ben), vagy az állami iskolához képest mindenképpen jóval kisebb arányban vannak halmozottan hátrányos helyzetü tanulók (a kivételek Jászapáti, Kiskőrös és Mezőcsát). 2010-ben négyböl három településen gettósodó vagy gettóiskola volt, 2016-ban ez az arány hétből négy . Ezek az iskolák nem felekezeti fenntartásban állnak, kivéve 2016-ban Jászapátiban, ahol a katolikus általános iskola a gettóiskola. Jól látni, hogy a felekezeti általános iskolák romaaránya annak települési eloszlását nézve aránytalanul alacsony (2010-ben megegyezik a szerkezetváltóéval) - vagy, mint ahogyan 2016-ban 7-ből 6 szerkezetváltó iskola: nem adtak meg romaarány adatot (2010-ben egy ilyen iskola volt). Mindezek alapján elmondható, hogy amennyiben a felekezeti fenntartó általános iskolai és szerkezetváltó gimnáziumi programot is kínál, karakteres eltérés leginkább a CSHI-átlagokban mutatkozik, kisebb mértékben a HHH- és romaarány-számokban is, jellemzően az általános iskolai képzés mutatói is a települési nem egyházi iskola mutatói felett vannak.

\section{Összefoglalás}

2010-ben, és egy fenntartóváltási hullámot követően, 2016-ban vizsgáltam a felekezetek iskoláinak helyzetét és hatását a települési (szelekciós) iskolastruktúrában.

A családiháttér-index mutatóval a szociokulturális előnyben-részesítést lehet megállapítani, a HHH és romaarányok vizsgálatával pedig a szocio-ökonómiai és etnikai alapú kizárás tendenciája mutatható ki. E három mutató segítségével tehát a tanulók településen belüli, iskolák közötti eloszlása, ennek változásai igen jól követhetőek voltak.

A magas státuszú családi háttérrel rendelkező tanulók felülreprezentáltsága az egyházi tulajdonú intézményekben már 2010ben is vitathatatlan volt, 2016-ra azonban nőtt azon települések száma is, ahol ez a különbség jól kimutatható, és nőtt magának a különbségnek a mértéke is. A felekezeti

A magas státuszú családi háttérrel rendelkezó tanulók felülreprezentáltsága az egyházi tulajdonú intézményekben már 2010-ben is vitathatatlan volt, 2016-ra azonban nótt azon települések száma is, ahol ez a különbség jól kimutatható, és nótt magának a különbségnek a mértéke is. A felekezeti és nem felekezeti fenntartású iskolák (kivéve az állami szerkezetváltó gimnáziumokat) tanulói összetételének különbsége kifejezet-

ten növekedett. A HHH-és romaarány-mutatók alapján a felekezeti iskolák jelentốs része a településen egy szelekciós szigetet képez. A társadalmi státusz és hátrányok mutatóinak településen belüli aránytalan eloszlása érzékelhetóen nó, az ilyen irányú változás különösen egyértelmú azokon a településeken, ahol 2010-ben nem volt egyházi iskolafenntartó. 
és nem felekezeti fenntartású iskolák (kivéve az állami szerkezetváltó gimnáziumokat) tanulói összetételének különbsége kifejezetten növekedett. A HHH- és romaarány-mutatók alapján a felekezeti iskolák jelentős része a településen egy szelekciós szigetet képez. A társadalmi státusz és hátrányok mutatóinak településen belüli aránytalan eloszlása érzékelhetően nő, az ilyen irányú változás különösen egyértelmü azokon a településeken, ahol 2010-ben nem volt egyházi iskolafenntartó. Mind a három mutatót figyelve két megállapítást tehetünk a 2010 és 2016 közötti folyamatról: (1) a felekezetek a településeknek, úgy tünik, eleve a ,jobb" - kedvezőbb mutatókkal rendelkező - iskoláit vették át, illetve (2) mintha a tanulóközösségek határozott homogenizálása zajlott volna - vagy zajlana éppen - le. A leglátványosabb talán az etnikai szelekció - és ennek következtében a szegregáció - folyamata: rohamosan emelkedik azon intézmények száma, ahol egyáltalán nincs roma tanuló, és jelentős mértékben nő azoknak az iskoláknak a száma is, ahol nagyon magas a roma tanulók koncentrációja. 2016-ra mind a vizsgált települések, mind az iskolák közel fele érintetté vált. A mozaikokból kikerekedik a kép: az egyre több településen egyre több felekezeti iskola az egyre kedvezőbb hátterű tanulói összetételével egy világos szelekciós alternatívát kínál a nem roma és nem szegénységben élő szülők számára; a HHH és roma gyermekeket távol tartja, így ők a település maradék iskolái között - azok saját iskolapolitikájától függően - oszlanak el. Így a folyamat vége a települési iskolák polarizációja: egyik végén állnak a felekezeti iskolák, a másik végén a gettósodó, gettó állami iskolák a nehéz körülmények között élőkkel és roma diákokkal.

Úgy gondolom, az első kutatási kérdésre egyértelmű választ kaptunk: a kutatásban szereplő felekezetek mint iskolafenntartók érzékelik a társadalom bizonyos csoportjainak részéről a szeparációs igényt, és őket választva célcsoportnak, ezt az igényüket kiszolgálják. Ezt a megállapítás tette Herman és Varga (2016) is. Ez a válasz a második kutatási kérdésre is - jól kiemelkedett a mintázata annak, hogy a felekezeti fenntartók kihasználják a törvényi szabályozás biztosította mozgásteret. Nyilván a beiskolázási kötelezettségnek megfelelően az általános iskolai képzésben valamilyen mértékben megjelenik a településre jellemző tanulói heterogenitás, de ha megnézzük az igen alacsonyan tartott hátránymutatókat, azt látjuk, hogy az egyházi intézmények a fennmaradó beiskolázható létszámmal ezt a nem túl szigorú kötelezettséget jól kompenzálják. A szerkezetváltó gimnáziumok pedig az egyházi tulajdonú intézményrendszerben is egyértelmúen és 100 százalékban a települési elitnek szóló ajánlatok.

Több esetben is fontosnak tartottam bemutatni az adathiányok számát-arányát. Ez jellemzően a roma tanulói arány esetében fordul elö - és pont ezért van jelentősége. A többi olyan adat, mely szelekciós mutató lehet, nem a fenntartótól és képviselőjétől (intézményvezető) származik: a családiháttér-indexet a Tanulói kérdőív alapján számíthatjuk ki, a HHH-arányt pedig az éves kötelező adatszolgáltatás során egyénileg regisztrálják. A romaarány az egyetlen mutató, amelyen keresztül manipulálható az iskoláról alkotott kép: egyrészt a szülők felé a kívánatosság szempontjából, másrészt az oktatásirányítás felé, mert az adatszolgáltatás elkerülése miatt nem derül ki egyértelmüen a szelekció müködése és mértéke.

Érdemes a vizsgált felekezetek iskolapolitikáját külön is jellemezni a rendelkezésre álló adatok figyelembevételével. A CSHI-mutatóval kapcsolatos eredmények alapján a katolikus intézmények esetében tapasztalható a legnagyobb mértékben a szociokulturális exkluzivitás, valószínüleg a nagyobb iskolalétszám miatt sokkal látványosabb, mint ugyanez a hasonló mértékben kirekesztő evangélikus iskolák esetében. A református és görögkatolikus iskoláknál is egyértelmű ez a törekvés. A hátránymutatókkal kapcsolatban a HHH- és romaarány esetében a leginkább szélsőséges, kizárást mutató számarányokat a református felekezet iskoláinál látjuk, illetve az evangélikus iskolák esetében. Ez a tendencia a katolikus és görögkatolikus iskoláknál is. Az evangélikus és görögkatolikus iskolák alacsony számuk miatt kevésbé árnyaltan jelennek meg, de vitán 
felül részt vesznek a helyi szelekciós folyamatokban. Az adatok alapján egyik felsorolt felekezet esetében sem kétséges a szelektivitás. A vizsgálatok során világossá vált, hogy a baptista felekezetről nem lesz elégséges információ bármiféle következtetés levonásához. A vizsgált települések körében összesen egy intézménnyel volt jelen ${ }^{1}$, így semmilyen érvényes, jól dokumentált megállapítást nem tehetek fenntartói viselkedésére, iskolapolitikájára vonatkozóan.

A kutatásban korlátozó tényezőt egyfelől a már jelzett adathiány jelentett, másfelől egy olyan adathiány, amelyröl tudunk Expanzió (2013) -, és talán még tehetetlenebbek vagyunk: az OKM-kérdőív kitöltésekor különösen jelentős a $\mathrm{HH}, \mathrm{HHH}$ tanulók hiánya. Ez magára a mérésre is igaz (nincs teszteredmény), de még erősebben a kérdőívek kitöltésére. Hogy nagyon pontosan fel lehessen mérni az állapotokat és szükségleteket, minél több, részletesebb adatra volna szükség.

Hangsúlyoztam, hogy a megállapítások érvényessége szigorú értelembe véve a vizsgálati körre vonatkozik. Nyilvánvaló, hogy ezt szükséges szélesíteni ahhoz, hogy minél megalapozottabban lehessen értékelni a különböző fenntartók iskolapolitikáját. Nem kívánom kétségbe vonni az egyházi fenntartású iskolák sok esetben valódi, a társadalmi esélyegyenlőtlenségeket csökkenteni kívánó szándékát. Ám a helyzet az, hogy ha egy iskola(rendszer) a különbözö (jogi, financiális, szociális státusz) kiváltságait és mozgásterét olyan módon használja fel, hogy középosztálybeli szülőket toborozzon, és őket megtartsa (elvárások, igények kielégítése), akkor az alapvető szándéktól, tudatosságtól teljesen függetlenül, a végeredmény tekintetében mindenképpen szelekciós csatornaként kezd müködni, melynek következtében hozzájárul a kirekesztés, a szegregáció növekedéséhez. Az egyenlő esélyeket biztosító oktatást elöíró nemzeti és nemzetközi szabályozók, a vallási értékeket tükröző elvek egyike sem engedi meg, hogy egy iskolafenntartó olyan iskolapolitikát alkalmazzon, melynek eredményeképpen sérül bármely gyermek minőségi oktatáshoz

1 A Magyarországi Baptista Egyház 19 olyan FEH fenntartója, ahol van 8. évfolyam. Ebből 13 egyiskolás településen van, egy van $2 \mathrm{FEH}$-es településen (Kisújszállás, amely beleesik a vizsgált települések körébe), egy 5 FEH-es településen, illetve van egy iskolája Pécsen és Miskolcon, és kettő Budapesten. A 19 általános iskola CSHI-átlaga -0,46, ahol a legalacsonyabb -1,93, a legmagasabb 0,93. A 19 FEH-ből csupán 5 CSHI-átlaga magasabb az országos CSHI-átlagnál $(-0,023)$.
Hangsúlyoztam, hogy a megállapitások érvényessége szigorú értelembe véve a vizsgálati körre vonatkozik. Nyilvánvaló, hogy ezt szükséges szélesiteni ahhoz, hogy minél megalapozottabban lehessen értékelni a különbözó fenntartók iskolapolitikáját. Nem kívánom kétségbe vonni az egyházi fenntartású iskolák sok esetben valódi, a társadalmi esélyegyenlótlenségeket csökkenteni kívánó szándékát. Ám a helyzet az, hogy ha egy iskola(rendszer) a különbözó (jogi, financiális, szociális státusz) kiváltságait és mozgásterét olyan módon használja fel, hogy középosztálybeli szülóket toborozzon, és óket megtartsa (elvárások, igények kielégitése), akkor az alapvetó szándéktól, tudatosságtól teljesen függetlenül, a végeredmény tekintetében mindenképpen szelekciós csatornaként kezd múködni, melynek következtében hozzájárul a kirekesztés, a szegregáció növekedéséhez. 
való hozzáférésének joga és lehetősége. Nem elfogadható, hogy bármelyik iskolahálózatot müködtető szervezet egy ilyen következményekkel járó iskolapolitikát ideologikus megfontolások alapján kíséreljen meg igazolni. Márpedig ami most folyik Magyarországon, az nem más, mint jól szervezett, szisztematikus települési kasztosodás, melyben bizonyos egyházak iskolapolitikájukkal részt vállalnak.

\section{Irodalom}

Csapó, B., Fejes, J. B., Kinyó, L. \& Tóth, E. (2019). Educational Achievement in Social and International Contexts. In Kolosi, T. \& Tóth, I. Gy. (szerk.). Social Riport 2019. Budapest: TÁRKI. 217-236.

Ercse Kriszta (2018). Az állam által ösztönzött, egyházasszisztált szegregáció mechanizmusa. In Fejes József Balázs \& Szűcs Norbert (szerk.). Én vétkem. Helyzetkép az oktatási szegregációról. Szeged: Motiváció Oktatási Egyesület. 177-199.

Expanzió (2013): A halmozottan hátrányos helyzetü tanulók kompetenciamérések során elért eredményeinek elemzése. http://www.oktatas.hu/pub_bin/dload/ kozoktatas/meresek/orszmer2013/kompetenciameres_hhh_tanulok_eredmenyeinek_elemzese.pdf

Fehérvári Anikó \& Széll Krisztián (2014). Méltányosság az oktatásban: tanulói eredmények, szülök, iskola. In Széll Krisztián (szerk.), Az OECD az oktatásról - adatok, elemzések, értelmezések. Budapest: Oktatáskutató és Fejlesztő Intézet. 41-51.

Hermann Zoltán \& Varga Júlia (2016). Állami, önkormányzati, egyházi és alapítványi iskolák: részarányok, tanulói összetétel és tanulói teljesítmények. In Kolosi Tamás \& Tóth István György (szerk.). Társadalmi Riport 2016. Budapest: TÁRKI. 311-333.

Kopp Erika (2015). Egyházi iskolák tanulói összetételének vizsgálata - Felekezeti különbségek a kompetenciamérések háttérváltozóinak elemzése alapján. In Pusztai Gabriella \& Lukács Ágnes (szerk.), Közösségteremtök: Tisztelgés a magyar vallásszociológusok nagy nemzedéke előtt. (Debreceni Egyetem - Magyar Tudományos Akadémia Debreceni Akadémiai Bizottság) Debrecen: Debrecen University Press. 197-225.

Lannert Judit, Németh Szilvia \& Szécsi Judit (2018). Szegregáló deszegregáció? In Fejes József Balázs \& Szücs Norbert (szerk.), Én vétkem. Helyzetkép az oktatási szegregációról. Szeged: Motiváció Oktatási Egyesület.

L. Ritók Nóra (2018). Egy helyi deszegregációs kezdeményezés tapasztalatai - Biharkeresztes, Komádi,
Berettyóújfalu. In Fejes József Balázs \& Szücs Norbert (szerk.), Én vétkem. Helyzetkép az oktatási szegregációról. Szeged: Motiváció Oktatási Egyesület.

Maussen, M. \& Bader, V. (2015). Non-governmental religious schools in Europe: institutional opportunities, associational freedoms, and contemporary challenges, Comparative Education, 51(1), 1-21. DOI: 10.1080/03050068.2014.935581

Merry, M. S. (2015). The conundrum of religious schools in twenty-first century Europe, Comparative Education, 51(1), 133-156. DOI: 10.1080/03050068.2014.935582

Nahalka István \& Zempléni András (2014). Hogyan hat az iskola/osztály tanulóinak heterogén/homogén összetétele a tanulók eredményességére? In Oktatási Hivatal (szerk.), Hatások és különbségek: Másodelemzések a hazai és nemzetközi tanulói képességmérések eredményei alapján. Budapest: Oktatási Hivatal. 91-166.

OECD (2012). Public and Private Schools: How Management and Funding Relate to their Socio-economic Profile. OECD Publishing. DOI: 10.1787/9789264175006-en

OECD (2016). PISA 2015 Results (Volume I). Excellence and Equity in Education, PISA. Paris: OECD Publishing. DOI: 10.1787/9789264266490-en

Radó Péter (2018). A közoktatás szelektivitása mint a roma szegregáció általános kontextusa. In Fejes József Balázs \& Szücs Norbert (szerk.). Én vétkem. Helyzetkép az oktatási szegregációról. Szeged: Motiváció Oktatási Egyesület. 31-55.

Tomasz Gábor (2017). Erősödő egyházi jelenlét az oktatásban. Educatio, 26(1), 94-112. DOI: 10.1556/2063.26.2017.1.9

Zolnay János (2018). Kasztosodó közoktatás, kasztosodó társadalom. In Fejes József Balázs \& Szűcs Norbert (szerk.), Én vétkem. Helyzetkép az oktatási szegregációról. Szeged: Motiváció Oktatási Egyesület. 211-231. 


\section{Melléklet}

1. számú Melléklet: Felekezetekre vonatkozó adatok összesített táblázata (forrás: OKM 2010-2016. évi 8. évfolyamos adatbázis)

\begin{tabular}{|l|c|c|c|c|}
\hline & \multicolumn{2}{|c|}{ FEH-ek } & \multicolumn{2}{c|}{ CSHI } \\
\hline Felekezetek & $\begin{array}{c}\text { 2010-ben } \\
\text { FEH-ek } \\
\text { száma }\end{array}$ & $\begin{array}{c}\text { 2016-ban FEH- } \\
\text { ek száma }\end{array}$ & $\begin{array}{c}\text { 2010-ben településén } \\
\text { a legmagasabb CSHI } \\
\text { átlaggal rendelkezik }\end{array}$ & $\begin{array}{c}\text { 2016-ban településén a } \\
\text { legmagasabb CSHI átlaggal } \\
\text { rendelkezik }\end{array}$ \\
\hline katolikus & 25 & 45 & $13-52 \%$ & $27-60 \%$ \\
\hline református & 23 & 35 & $8-34,8 \%$ & $21-60 \%$ \\
\hline evangélikus & 4 & 6 & $2-50 \%$ & $3-50 \%$ \\
\hline görögkatolikus & 2 & 5 & $1-50 \%$ & $4-80 \%$ \\
\hline baptista & 0 & 1 & 0 & $1-100 \%$ \\
\hline
\end{tabular}

\begin{tabular}{|l|c|c|c|c|}
\hline & \multicolumn{4}{|c|}{ HHH-arány } \\
\hline Felekezetek & $\begin{array}{c}\text { 2010-ben a településen } \\
\text { legalacsonyabb HHH } \\
\text { aránnyal rendelkezik }\end{array}$ & $\begin{array}{c}\text { 2016-ban a településen } \\
\text { legalacsonyabb HHH } \\
\text { aránnyal rendelkezik }\end{array}$ & $\begin{array}{c}\text { 2010-ben } \\
\text { nincs HHH } \\
\text { tanulója }\end{array}$ & $\begin{array}{c}\text { 2016-ban } \\
\text { nincs HHH } \\
\text { tanulója }\end{array}$ \\
\hline katolikus & $12-48 \%$ & $23-51,1 \%$ & $9-36 \%$ & $13-28,8 \%$ \\
\hline református & $12-52,2 \%$ & $20-24,2 \%$ & $8-34,8 \%$ & $10-28,6 \%$ \\
\hline evangélikus & $3-75 \%$ & $2-33,3 \%$ & $3-75 \%$ & $2-33,3 \%$ \\
\hline görögkatolikus & $1-50 \%$ & $3-60 \%$ & $1-50 \%$ & $1-20 \%$ \\
\hline baptista & 0 & $1-100 \%$ & 0 & 0 \\
\hline
\end{tabular}

\begin{tabular}{|c|c|c|c|c|c|c|}
\hline & \multicolumn{6}{|c|}{ Romaarány } \\
\hline Felekezetek & $\begin{array}{c}\text { 2010-ben } \\
\text { településén } \\
\text { legalacsonyabb } \\
\text { roma aránnyal } \\
\text { rendelkezik }\end{array}$ & $\begin{array}{l}\text { 2016-ban } \\
\text { településén } \\
\text { legalacsonyabb } \\
\text { roma aránnyal } \\
\text { rendelkezik }\end{array}$ & $\begin{array}{c}\text { 2010-ben } \\
\text { nincs } \\
\text { roma } \\
\text { tanulója }\end{array}$ & $\begin{array}{c}\text { 2016-ban } \\
\text { nincs } \\
\text { roma } \\
\text { tanulója }\end{array}$ & $\begin{array}{c}\text { 2010-ben } \\
\text { nem adott } \\
\text { roma- } \\
\text { arányról } \\
\text { adatot }\end{array}$ & $\begin{array}{c}\text { 2016-ban } \\
\text { nem adott } \\
\text { roma- } \\
\text { arányról } \\
\text { adatot }\end{array}$ \\
\hline katolikus & $10-40 \%$ & $20-44,4 \%$ & $1-4 \%$ & $5-11,1 \%$ & $4-16 \%$ & $7-15,5 \%$ \\
\hline református & $14-60,9 \%$ & $22-62,9 \%$ & $1-4,3 \%$ & $7-20 \%$ & $2-8,7 \%$ & $5-14,3 \%$ \\
\hline evangélikus & $1-25 \%$ & $1-16,6 \%$ & 0 & 0 & $1-20 \%$ & $2-33,3 \%$ \\
\hline görögkatolikus & $1-50 \%$ & $3-60 \%$ & 0 & 0 & $1-50 \%$ & $2-40 \%$ \\
\hline baptista & 0 & 0 & 0 & 0 & 0 & 0 \\
\hline
\end{tabular}




\begin{tabular}{|c|c|c|c|c|}
\hline \multirow[b]{2}{*}{ Felekezetek } & \multicolumn{2}{|c|}{ Gettó } & \multicolumn{2}{|l|}{ Szórás } \\
\hline & $\begin{array}{l}\text { 2010-ben } \\
\text { iskolái gettó/ } \\
\text { gettósodó } \\
\text { településen } \\
\text { voltak }\end{array}$ & $\begin{array}{l}\text { 2016-ban } \\
\text { iskolái gettó/ } \\
\text { gettósodó } \\
\text { településen } \\
\text { voltak }\end{array}$ & $\begin{array}{l}\text { Felekezeti FEH-ek száma olyan } \\
\text { településeken (39), ahol nőtt } 2010 \\
\text { és } 2016 \text { között a települési CSHI } \\
\text { átlagok szórása }\end{array}$ & $\begin{array}{l}\text { Ezek aránya a } \\
\text { felekezet többi } \\
\text { iskolájához } \\
\text { képest }\end{array}$ \\
\hline katolikus & $9-36 \%$ & $20-44,4 \%$ & 25 & $55,50 \%$ \\
\hline református & $11-47,8 \%$ & $16-45,7 \%$ & 14 & $40 \%$ \\
\hline evangélikus & 0 & $1-16,6 \%$ & 2 & $33,30 \%$ \\
\hline görögkatolikus & 0 & $2-40 \%$ & 3 & $40 \%$ \\
\hline baptista & 0 & 0 & 1 & $100 \%$ \\
\hline
\end{tabular}

Absztrakt

2010 óta jelentősen megnőtt mind az egyházi fenntartású iskolák, mind az egyházi fenntartású iskolák tanulóinak aránya, így az egyházi fenntartók iskolapolitikája képes hatást gyakorolni az oktatási rendszer egészére. Ugyanebben az időszakban a kormányzat részéről egyértelmúen azonosítható az egyházi fenntartókat preferáló viselkedés (pl. kommunikáció, finanszírozás, diszkrecionális jogosultságok biztosítása). Figyelembe véve e két folyamatot, illetve a magyar oktatási rendszert jellemző szélsőséges, szociokulturális, szocioökonómiai alapú szelektivitást, indokolt az egyháziiskola-hatás vizsgálata. A kutatás azoknak a 2, 3 és 4 iskolás településeknek vizsgálta a szelekciós struktúráját, ahol a legnagyobb hatáspotenciállal rendelkező felekezeteknek (katolikus, református, evangélikus, görögkatolikus) volt 2016-ban iskolájuk. A 2010 és 2016 között az Országos Kompetenciamérés 8. évfolyamos adatbázisainak három mutatója - családiháttér-index (CSHI), halmozottan hátrányos helyzetü $(\mathrm{HHH})$ és roma tanulók aránya - segítségével követhető a tanulók településeken belüli eloszlása és ennek változása. Az elemzés a 2010-es évben is nagymértékü szelekciót talált a vizsgált településeken. Az egyházi iskolák tanulóinak CSHI-átlaga az esetek döntő többségben a települési átlag felett van. A HHH tanulók az egyházi iskoláknak közel feléből teljességgel hiányoznak. A roma tanulók tekintetében 2016-ra a települések egyötödén az egyházi iskolák megvalósították a teljes etnikai szelekciót. Ezzel összefüggésben a gettósodó és gettóintézmények száma és aránya extrém mértékben megnőtt. Külön vizsgálva azokat a településeket, ahol a kiinduló évben nem volt egyházi fenntartó - és azokat, ahol szélsőséges roma tanulói koncentráció sem -, az látható, hogy a települési szelekciós iskolastruktúrákban az egyházi iskolák belépése egyértelmüen egy durván polarizált tanulói eloszlást eredményezett a társadalmi hátrányok mentén. A vizsgálatban szereplő felekezeti fenntartók mindegyikéről megállapítható, hogy a beiskolázás szempontjából mindig a relatíve magas státuszú családok gyermekeit (nem $\mathrm{HHH}$, nem roma) részesítik előnyben. 